\title{
Dynamism and competitiveness of mexican beef, a focus of market diversification
}

\section{Dinamismo y competitividad de la carne de bovino mexicana, un enfoque de diversificacion de mercados}

\author{
CARRILLO-ÁNGELES, Rebeca Yurani ${ }^{1,2 * \dagger}{ }^{1}$, CRUZ-SORIANO, Emmanuel ${ }^{1}$ and ESCAMILLA- \\ SALAZAR, Zugaide ${ }^{2}$
}

${ }^{1}$ Universidad Politécnica de Atlacomulco

${ }^{2}$ Universidad Autónoma del Estado de México

ID $1^{\text {st }}$ Author: Rebeca Yurani, Carrillo-Ángeles / ORC ID: 0000-0002-6380-5805, arXiv ID: ryuranica, CVU CONACYT ID: 175471

ID $1^{\text {st }}$ Coauthor: Emmanuel, Cruz-Soriano / ORC ID: 0000-0003-0393-4936, arXiv ID: emmanuelcruz1991

ID $2^{\text {nd }}$ Coauthor: Zugaide, Escamilla-Salazar / ORC ID: 0000-0002-3666-4760

DOI: $10.35429 / J B D S .2019 .15 .5 .14 .20$

Received March 15, 2019; Accepted May 25, 2019

\section{Abstract}

In Mexico, the production and export of bovine have remained competitive, placing it within the top ten countries due to its competitiveness which is based on weather conditions, the production of cereals for food and the commercial relationship with the United States. In this regard, Mexico, with the signing of the North American Free Trade Agreement (NAFTA), promotes international trade with the United States and Canada, with the objective of eliminating obstacles to trade, facilitating the cross-border circulation of goods and services, promoting fair competition in the free trade zone, increases investment opportunities, among others aims (Ministry of Economy, 1993). At the beginning of the agreement, Mexico achieved short-term macroeconomic objectives of stability, economic growth, and inflation control, however, in the long term it has not meant an increase in the standard of living of Mexicans, therefore, Mexico decided to diversify markets of export through bilateral trade agreements with other countries. As a consequence, the objective of this research is to perform an analysis of the commercial position of Mexican beef (2002-2016), obtaining the Grubel \& Lloyd index and the grown rate by time interval, concluding that there is a commercial dynamism of this Mexican product..

Competitiveness, Comercial Positioning, Diversification

\begin{abstract}
Resumen
En México la producción y exportación de ganado bovino se han mantenido como actividades competitivas, ubicándolo dentro de los principales diez países, dicha competitividad está basada en las condiciones climáticas, en la producción de cereales para su alimentación y la relación comercial con Estados Unidos. En ese sentido, México con la firma del Tratado de Libre Comercio de América del Norte (TLCAN) impulsó el comercio internacional con Estados Unidos y Canadá teniendo como objetivos eliminar obstáculos al comercio, facilitar la circulación transfronteriza de bienes y servicios, promover la competencia leal en la zona de libre comercio, aumentar las oportunidades de inversión, entre otros (Secretaría de Economía, 1993). Al comienzo del tratado, México logro a corto plazo los objetivos macroeconómicos de estabilidad, crecimiento económico y control inflacionario, sin embargo, a largo plazo no ha significado un aumento en el nivel de vida de los mexicanos, por ello, México decidió diversificar mercados de exportación a través de tratados de comercio bilaterales con otros países. Como consecuencia, el objetivo de esta investigación es realizar un análisis de la posición comercial de la carne de bovino mexicana (2002-2017), obteniendo el índice Grubel \& Lloyd y tasas promedio de crecimiento en intervalos de tiempo, concluyendo que existe dinamismo comercial de dicho producto mexicano.
\end{abstract}

\section{Competitividad, Posicionamiento Comercial, Diversificación}

Citation: CARRILLO-ÁNGELES, Rebeca Yurani, CRUZ-SORIANO, Emmanuel and ESCAMILLA-SALAZAR, Zugaide. Dynamism and competitiveness of mexican beef, a focus of market diversification. Journal of Business Development Strategies. 2019, 5-15: 14-20.

\footnotetext{
* Correspondence to Author (email: deurueta@xanum.uam.mx)

$\dagger$ Researcher contributing first author.
} 


\section{Introduction}

Globalization has imposed as one of the features of international economy at the end of the century, which is characterized by the convergence towards more open and competitive markets; in that sense, the need to reach a more competitive livestock is established as a condition to achieve an efficient international insertion. The current agricultural policy scheme, both in Mexico and in the world, as well as global trade trends, open new marketing opportunities for various agricultural products.

Likewise, within the livestock subsector, the production and consumption of meat are the most important items in the world, in the case of the production of beef worldwide; in 2017, $66,250,349$ tonnes were produced (FAO, 2019), which is considered a historical maximum. In the same year, the main producers of beef were the United States of America (17.97\%), the European Union (15.85), Brazil (14.41\%), Argentina (4.28\%) and Australia (3.09\%) respectively (FAO, 2019).

In Mexico, beef production is reported with a production volume of $1,925,901$ tons; which is equivalent to $2.90 \%$ of the world production.

Trade openness in the world, especially in Mexico, generated new realities which affected the productive chains. The beef chain was very complex, because it competed against the leading country of world production; likewise, most of the cattle production was carried out under extensive conditions, added to the fact that there was a poor integration of its links.

However, Mexican livestock has moved from a process of extensive cattle raising and export of live cattle, to technified and exportoriented processes of fresh and frozen meat of better quality.

It is appropriate to point out that cattle livestock for meat is an important activity in Mexico, because it takes advantage of natural resources in more than $50 \%$ of the national territory, for its contribution of meat as a staple food, for the generation of foreign exchange with exports, and for its contribution to rural development through job creation (Marquez, 2004).
Furthermore, in the context of International Trade, Mexico ranks sixth among world producers and ninth in terms of exports, with $89 \%$ of these exports destined for the United States of America market (USDA, 2016).

Concerning the above, it is important to note that in 2017 there was uncertainty and concern in the North American Free Trade Agreement (NAFTA) region, specifically in Mexico, regarding the possible results of a renegotiation or even its cancellation. The responsible Mexican authorities indicated that the NAFTA renegotiation process could be completed by the end of 2018 or extended to 2019.

In this context, this research work aims to perform an analysis of the commercial position of Mexican beef (2002-2016) within the region of the North American Free Trade Agreement (NAFTA) and in turn analyze Mexico's relationship with new business partners, to suggest potential markets for that product.

The analysis of the commercial position of Mexican beef was obtained from the Grubel \& Lloyd index, which has not been used in previous research on this product. Annual growth rates and average growth rates were also obtained with time periods.

The central hypothesis of this research states that the increase in the production of Mexican beef is directly reflected in the exports made, which indicates a greater market share.

Based on the foregoing, the main reasons for the Mexican commercial opening before and after NAFTA are briefly presented in the first section of this investigation.

In the second section, an overview of the production of Mexican beef is provided, highlighting the main producing states, and some strategies used by producers to create new market spaces and their consolidation.

Finally, in the third section, a general outlook of the North American Free Trade Agreement is presented, where the main reasons after 23 years in force are emphasized, as well as the objectives of the United StatesMexico-Canada Agreement (USMCA). 


\section{The Mexican commercial opening and the beef market}

In Mexico, commercial integration began during the sixties. As part of the context, the national economy was going through economic crises (1977-1982), subsequently, there was an economic boom derived from the increase in oil prices in international markets. However, this was not enough since market prices fell together with another phenomenon presented, considered "capital flight." At the beginning of the 1980's the opening to foreign trade was reduced, but it was during that same period, when there was greater dynamism, based on the consolidation of NAFTA in 1994; a period in which a growing coefficient of openness was reported. Likewise, over time there has been a greater concentration of foreign trade between Mexico and the United States of America through this treaty.

It is worth mentioning that, at the beginning of Mexico in NAFTA, its global indices of intraindustrial trade increased, until 2001 when they diminished, due to the economic recession of the United States.

In connection to the previous idea, it should be noted that Mexico has remained among the first ten countries in the production and export of live cattle since the 1980's and 1990 's. However, it was not included in the production of fresh or frozen meat as it is today. In 1994, the countries that dominated around half of the global meat production were the United States, some countries of the European Union, Brazil and Argentina, but in 1995 China began to enter the market (Chauvet, 1999).

Currently, the demand for meat in the world has presented a notable increase, derived from the following circumstances: population growth, salary increases and changes in food preferences, and it is expected that by 2050 most of the growth will take place in developing countries (FAO, 2019).

\section{Cattle in Mexico}

During the 21st century, Mexico's participation in the agricultural sector increased from $9.91 \%$ in 2013 to $13.72 \%$ in 2012. It also began to gain strength in exports of fresh and frozen meat, having greater production dynamics and generating added value, which were not achieved in previous decades (Ríos, 2015).
Between 2007 and 2016, the production of beef in Mexico increased by $1.8 \%$, similar to that of China, which increased by $1.3 \%$; conversely, the United States reported a decrease of $0.6 \%$. In this same period, consumption rose in countries such as China, $2.7 \%$ annually, Turkey $14.9 \%$ and India $3.5 \%$. On the other hand, the countries that decreased their consumption were the United States $1.0 \%$, the European Union $1.1 \%$ and Mexico $0.9 \%$, due to high meat prices and dietary changes.

Beef production in 2016 was structured as follows: Veracruz (13.4\%), Jalisco (11.5\%), Chiapas (6.1\%), San Luis Potosí (5.5\%), Sinaloa (4.9\%), Baja California (4.8\%), Durango (4.5\%), Michoacán (4.1\%), Chihuahua $(4.0 \%)$ and Sonora (3.7\%); in these 10 states, $62.5 \%$ of national production concentrated. In the same year, due to the increase in the price of beef, farmers were encouraged to fattening cattle for longer in order to increase the production of meat in greater weight and decrease the number of heads.

In 2017, high levels of production were achieved in certain basic products such as: cereals, some types of meat, dairy products and fish. This productive increase was due to the escalation in demand, based on the increase in per capita income in China, which has especially boosted the demand for meat and fish. (OECD/FAO, 2018).

Currently, in Mexico there are 1,151 slaughterhouses, only 52 are Federal Inspection Type (TIF) for cattle $(4.5 \%)$ and the rest are municipal (López, 2010).

Likewise, more than $80 \%$ of the volume of exports of meat and edible cattle offal are carried out by only 30 companies. These establishments are distinguished by the type of products and services they have generated to access new markets. Their main strategies are based on the investment of: factors of animal production that directly affect the quality of meat; developing schemes for the supply of specialized livestock for meat; the presentation of the product, where refrigerated, frozen and vacuum-packed products are handled, ensuring the quality and safety of their products until they reach the consumer; and the diversification of markets that highlights national consolidation, as well as the use of spaces in international trade without neglecting local and regional markets.

CARRILLO-ÁNGELES, Rebeca Yurani, CRUZ-SORIANO, Emmanuel and ESCAMILLA-SALAZAR, Zugaide. Dynamism and competitiveness of mexican beef, a focus of market diversification. Journal of Business Development Strategies. 2019. 
Nonetheless, López (2010), indicates that in terms of market diversification, the capacity developed by companies to enter different markets is low and concentrated in the United States of America.

\section{NAFTA and its transition to USMCA}

With the signing of the North American Free Trade Agreement (NAFTA), Mexico boosted international trade with the United States of America and Canada, with the following main objectives: to eliminate trade barriers and facilitate the cross-border movement of goods and services between the three countries; to promote conditions of fair competition in the free trade zone; to substantially increase investment opportunities in the territories of the parties; among others (Ministry of Economy, 1993). In the beginning, Mexico achieved the macroeconomic objectives of stability, economic growth and inflation control in the short term. However, in the long term it has not meant an increase in the standard of living of the Mexican population; it has not led to generation of products with high regional content of value and shared production among the member countries. On the other hand, it has achieved a certain level of integration of its production processes, although it maintains a commercial dependence with the United States of America (Ibarra, 2014).

In 2017, after 23 years of operation, the renegotiation of NAFTA began. The Mexican government determined certain priorities grouped into four thematic axes: the first, to strengthen the competitiveness of North America through clear rules, expedited procedures and the elimination of trade barriers to facilitate access to agricultural products; a second axis was to move towards inclusive and responsible regional trade; the third, sought to take advantage of the opportunities of the economy of the 21 st century; and the last axis, promoted the certainty of trade and investment in North America.

After a year of NAFTA negotiations, the United States-Mexico-Canada Agreement was implemented, which is based on: "supporting mutually beneficial trade that leads to more free and fair markets, and solid economic growth in the region." (NAFTA, 2018).
However, despite the signing of the USMCA, Mexico must bet on market diversification and take advantage of other treaties, focusing on countries where there is market growth, presented as stabilizers of the global economy, with the objective of preventing lag in times of economic growth.

\section{Methodology to be developed}

In order to determine the commercial position of Mexican beef (2002-2016), and the commercial dynamism that it presents, it is assumed that increases in production and export indicate a greater participation in the market.

In this context, the Grubel Lloyd index is used as an indicator of commercial specialization, which is obtained as follows:

$\operatorname{IGLL}=\frac{1-\Sigma\left|X_{i j}^{k}-M_{i j}^{k}\right|}{\Sigma\left(X_{i j}^{k}+M_{i j}^{k}\right)}$

Where:

$X_{i j}^{k}=$ Corresponds to the exports of the product or $k$ group of the $i$ country in relation to the $j$ country, in a given year or period.

$M_{i j}^{k}=$ Corresponds to the imports of the product or $k$ group of the $i$ country in relation to the $j$ country, in a given year or period.

The ranges vary from 0 to 1 , where, if the IGLL is closer to zero, it is assumed that trade consists only of imports or exports, generating inter-industrial trade. On the contrary, when the IGLL is close to one, it indicates that imports and exports are equal, that is, it is an intra-industrial trade.

Qasmi \& Fausti (1999) propose a classification in four groups:

0.00 to 0.25 strong inter-industrial commercial trend.

0.25 to 0.50 weak inter-industrial commercial trend.

0.50 to 0.75 weak intra-industrial commercial trend.

0.75 to 1.00 strong intra-industrial commercial trend. 
The Grubel Lloyd index has been used in different investigations; however, it is appropriate to mention that there are no previous studies where this index is used to explain the commercial trend (dynamism) of Mexican beef.

That said, Rosales, (2013) in the study titled: "The Dynamism of China and Emerging Asia: Opportunities and Challenges for Latin America and the Caribbean" refers to the analysis of intra-industry trade based on the methodology devised by Grubel and Lloyd to measure the level of trade flows in the same sector between countries and regions.

Banterle \& Carraresi (2006), in their study: "International Trade and the Analysis of Competitiveness in the European Union: The Cases of the Prepared Meat Sector" use the Grubel and Lloyd index to know the intraindustrial trade of the prepared meat sector in EU countries.

The source of data collection for this investigation was The United Nations Commodity Trade Statistics Database (UN Comtrade), where the unit value of tons of cattle meat exports and imports were obtained. The countries that make up the North America region were selected due to the strong established commercial relationship derived from NAFTA. On the other hand, the Asian countries China, Korea and Japan were selected because there is a potential to increase trade.

Likewise, average growth rates were obtained in time intervals (2002-2016), in terms of production and export in the selected countries.

\section{Results}

Table 1 shows the Grubel Lloyd index; the index shows results ranging between 0 and 1 .

\begin{tabular}{|l|l|}
\hline \multicolumn{1}{|c|}{ Country } & \multicolumn{1}{c|}{ IGLL } \\
\hline Mexico - USA & 0.722422359 \\
\hline Mexico - Korea & 0 \\
\hline Mexico - Japan & 0 \\
\hline Mexico - Canada & 0.054879784 \\
\hline Mexico - China & 0 \\
\hline
\end{tabular}

Table 1 Grubel Lloyd Index (2002-2016)

Source: The United Nations Commodity Trade Statistics Database (UN Comtrade), 2019
Mexico presents a Grubel Lloyd index of 0.722422359 with the USA as shown in table 1. According to the ranges established by Qasmi \& Fausti (1999), trade would have a weak intra-industrial trend; however, it is very close to moving to a strong intra-industrial trend at the time when its imports are very similar to its exports. By producing and exporting, we get the advantage of doing so with economies of scale, which allows to reduce costs and, therefore, have competitive selling prices, in addition to strengthening the exchange relationship with that country.

On the other hand, Mexico with Canada, Korea, China and Japan presents a strong interindustrial trade trend. Since the indices are in the range of 0.00 to 0.25 , trade goes in only one direction, which means that there is only Mexican beef export to these regions, generating a diversification of markets.

Graph 1 shows the dynamism of annual production growth in the selected countries. It is important to note that the average growth rates in the time interval (2002-20016) were positive, that is, there is an increase in production. Such is the case of Korea $(1.9346 \%)$, Mexico $(1.8319 \%)$ and the United States of America (0.0096\%) respectively.

Conversely, there are negative rates, that is, there is a decrease in production in China (4.8896\%), Canada (-2.5551) and Japan ($0.8914 \%)$.
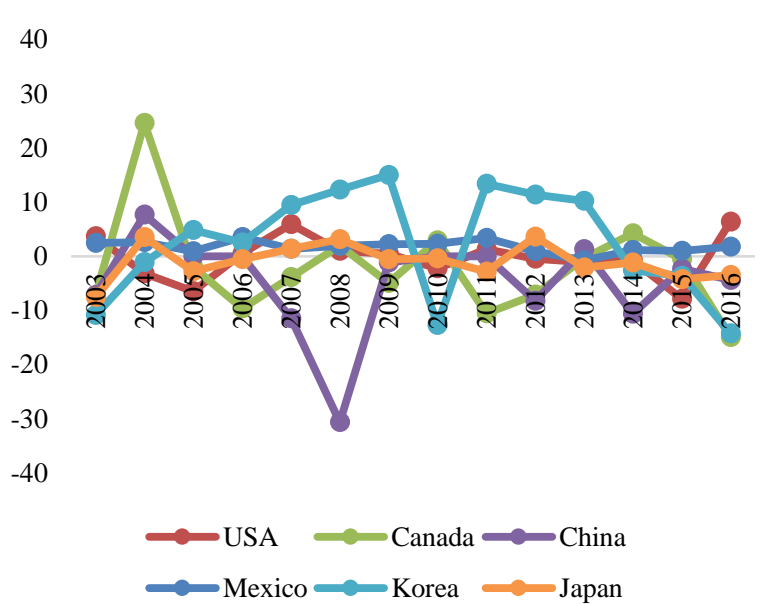

Graph 1 Annual growth of beef production 2019 Source: The United Nations Commodity Trade Statistics Database (UN Comtrade), 2019

Graph 2 reflects the behavior of average export growth during the analyzed period. 
Regarding the dynamism of exports, Korea presented the highest average growth rate $(38.2700 \%)$, followed by Mexico (36.7534\%), China (17.7778\%) and the United States of America (5.0699\%).

In the case of Japan and Canada, decreasing rates of $-17.1802 \%$ and $-7.1777 \%$ were obtained, respectively.

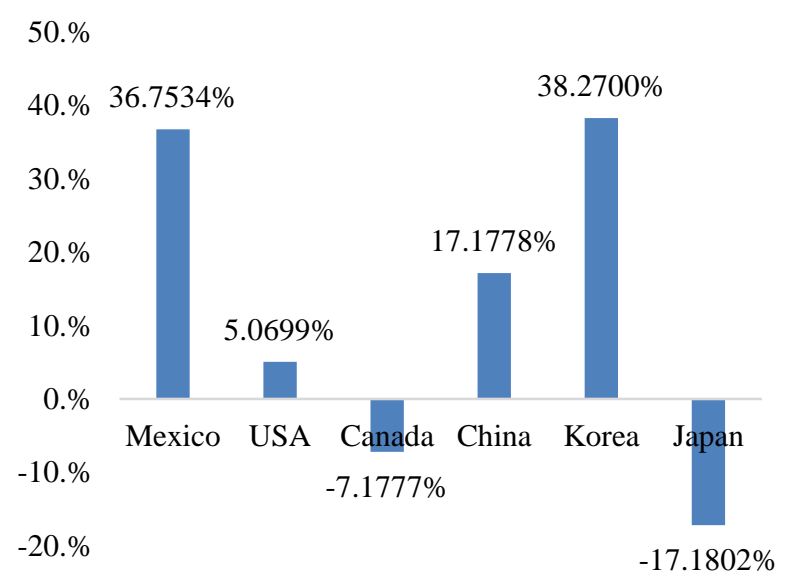

Graph 2 Average growth of beef exports 2019 Source: The United Nations Commodity Trade Statistics Database (UN Comtrade), 2019

It is appropriate to mention that, despite the results obtained in the growth rates of production and exports, the trade balance indicates that the United States of America, Canada and Mexico, respectively, are the markets that report surplus trade balance, that is, the volumes of export are higher in relation to import volumes.

In opposition, Korea, China and Japan have a negative trade balance, which indicates that in the short term they may be potential markets for the placement of Mexican beef.

\section{Acknowledgments}

The authors express their gratitude to the Polytechnic University of Atlacomulco for the facilities granted for the realization of this research.

\section{Conclusions}

In conclusion and based on the results obtained, Mexico should not focus on a single market, it should diversify beef exports and satisfy Asian markets that, in addition to being potential markets, are representatives of global growth.
In addition to commercial diversification, Mexico has to strengthen its internal market to achieve greater economic growth.

Moreover, in the diversification of markets, the different commercial ties and their tariff benefits must be exploited. In the same way, strategies based on the promotion and presence in international fairs should be proposed, in order to achieve competitive advantages.

\section{References}

Banterle, A. and Carraresi, L. (2006) "International Trade and Competitivene s s Analysis in the European Union: the Case of Prepared Meat Sector", In: 98th EAAE Seminar Marketing Dynamics within the Global Trading System: New Perspectives, Chania, Crete, Greece as in: 29 June - 2 July, 2006

Chuavet, M. (1999) La ganadería bovina de carne en México: del auge a la crisis. Universidad Autónoma MetropolitanaAzcapotzalco. Biblioteca de Ciencias Sociales y Humanidades-Serie Sociología, Mexico.

Fideicomiso Instituidos en Relación con la Agricultura (2018) Panorama Agroalimentario Carne de Bovino 2017. Accessed in April 29, 2019:

https://www.gob.mx/cms/uploads/attachment/fi le/200639/Panorama_Agroalimentario_Carne_d e_bovino_2017_1_.pdf.

López Arévalo, Jorge Alberto \& Rodil Marzábal, Óscar. (2008). Comercio intraindustrial e intra-firma en México en el contexto del proceso de integración de América del Norte (1993-2006). Economía UNAM, 5(13), 86-112.

López Palacios, María Guadalupe \& Muńoz Rodríguez, Manrrubio (2010). Innovación en valor en la industria cárnica bovina mexicana: estrategias que adoptan los líderes de mercado. Revista Mexicana de Ciencas Pecuarias 2010. 1(4):417-432.

Márquez Sánchez, Isaac, \& García Mata, Roberto (2004).El efecto de las importaciones de carne bovina en el mercado interno mexicano, 1991-2001. Colegio de Postgraduados. Agrociencia, 38(1), 121-130. 
Organización de las Naciones Unidas para la Alimentación Agraria (2019) Producción y sanidad animal. Accessed in April 28, 2019: http://www.fao.org/ag/againfo/themes/es/meat/ home.html.

Qasmi, Bashir \& Fausti, Scott. (1999). Nafta Intra Industry Trade In Agricultural Food Products. Western Agricultural Economics Association, 1999 Annual Meeting, July 11-14, 1999, Fargo, ND.

Ríos Flores, Jesús Armando, \& Castillo Arce, Miriam Liliana. (2015). La competitividad de la carne fresca de res mexicana en el mercado estadounidense. Estudios fronterizos, 16(32), 221-245.

Rosales, V. O. (2013). El dinamismo de China y Asia emergente: oportunidades y desafíos para América Latina y el Caribe. Santiago de Chile: Universidad Miguel de Cervantes/Instituto Latinoamericano de Relaciones Internacionales/JC Sáez Editor.

Secretaría de Economía (1993) Tratado de Libre Comercio de Norte América. Accessed in April 29, 2019: http://www.economiasnci.gob.mx/sicait/5.0/doctos/TLCAN.pdf.

Servicio de Información Agroalimentaria y Pesca (2018). Altas Agroalimentario. Accessed in April 29, 2019: https://nube.siap.gob.mx/gobmx_publicaciones _siap/pag/2018/Atlas-Agroalimentario-2018.

The United Nations Commodity Trade Stadistics Database, (2019).

United States Deparment of Agriculture. (2016). Foreing Agriculture Service. 